\title{
TNFRSF13B wt Allele
}

National Cancer Institute

\section{Source}

National Cancer Institute. TNFRSF13B wt Allele. NCI Thesaurus. Code C127902.

Human TNFRSF13B wild-type allele is located in the vicinity of 17p11.2 and is approximately $42 \mathrm{~kb}$ in length. This allele, which encodes tumor necrosis factor receptor superfamily member 13B protein, is involved in ligand-mediated signaling and immunity. 